\title{
Efficacy of Solvent Extracts of Some Medicinal Plants for Potential Antibacterial Activity.
}

\author{
Chandrashekhar J.Chandekar ${ }^{1}$ and Priya L. Lokhande ${ }^{2}$ \\ 1, 2- Department of Microbiology \& Biotechnology, \\ Shri Shivaji Science College, Congress Nagar, Nagpur-440012. \\ Email: chandekarc@yahoo.com
}

\begin{abstract}
:
Different solvent extracts of the leaves of Acacia Arabica, Ailanthus excelsa, Alstoniascholaris, Callistemomlanceolantus, Casurina equisetifolia, Catharanthus roseus, Grevellia robusta, Moringa oleifera, Psidium guava, Saraca indica, Tamarindus indicum,Vitex negundo and Thuja compacta were investigated for their antibacterial activity on Escherchia coli NCIM- 2931,Proteus vulgaris NCIM2857, Pseudomonas auriginosa NCIM-5029, Staphylococcus aureus NCIM5021,Bacillus cereus NCIM-2155, Bacillus subtilis NCIM-2063, and Bacillus megaterium NCIM-2087. $50 \mu 1$ of solvent extract is used to test antibacterial activity using agar well diffusion method with well size of $5 \mathrm{~mm}$ diameter using High sensitivity test agar medium. Acetone and Methanol extracts of Acacia Arabica, Callistemom lanceolantus, Casurina equisetifolia, Psidium guava, Saraca indica, and Thuja compacta showed significant activity against tested bacteria. Psidium guava extracts in acetone,chloroform, methanol and petroleum ether, are active against all bacteria tested except Bacillus cereus. Saraca indica's extract in acetone, chloroform, methanol and petroleum ether are active against all Gram positive bacteria tested.
\end{abstract}

\section{Key words:}

Solvent extracts, Antibacterial activity, agar well diffusion method.

\section{Introduction:}

Medicinal plants form the backbone of traditional system of medicine in India. Pharmacological studies have acknowledged the value of medicinal plants as potential source of bioactive compounds (Prusti et.al., 2008). Phyto chemicals from medicinal plants serve as lead compounds in drug discovery and design (Chakravarthy and Gode, 1985; Ebi and Ofoefule, 2000). Medicinal plants are rich source of novel drugs that forms the ingredients in traditional system of medicines, modern medicines, nutraceuticals, food 
supplements, folk medicines, pharmaceutical intermediates, bioactive principles and lead compounds in synthetic drugs (Ncube, 2008).

Nowadays multiple drug resistance has developed due to the indiscriminate use of commercial antimicrobial drugs commonly used in the treatment of infectious disease (Davis, 1994; Service, 1995). In addition to this problem, antibiotics are sometimes associated with adverse effects on the host including hypersensitivity, immune-suppression and allergic reactions (Ahmad et.al.,1998). This situation forced scientist to search for new antimicrobial substances. Given the alarming incidence of antibiotic resistance in bacteria of medical importance (Monroe and Polk, 2000), there is a constant need for new and effective therapeutic agents (Bhavani and Ballow 2000). Therefore, there is a need to develop alternative antimicrobial drugs for the treatment of infectious diseases from medicinal plants (Clark, 1996 and Cordell, 2000). Several screening studies have been carried out in different parts of the world. There are several reports on the antimicrobial activity of different herbal extracts in different regions of the world (Chung et al., 2004; De Boer et.al., 2004; Nair and Chanda, 2004; Nair et.al., 2005)

\section{Materials and methods:}

Test Organisms - Escherichia coli NCIM 2931, Proteus vulgaris NCIM 2857, Pseudomonas aureginosa NCIM 5029, Bacillus cereus NCIM 2155, Bacillus subtilis NCIM 2063, Bacillus megaterium and staphylococcus aureus NCIM 5021 these cultures were obtained from the National Collection of Industrial microorganisms, Pune.

Plants - Acacia arabica, Ailanthus excelsa, Alstonia scholaris, Casurina equisitifolia, Catharanthus roseus, Callistemom lanceolantus, Grevellia robusta, Moringa oleifera, Psidium guayava, Saraca indica, Tamarindus indicum, Thuja compacta and Vitex negundo.

Aqueous extraction - Ten grams of dried plant material was extracted with $100 \mathrm{ml}$ of distilled water for 6 h.at slow heat. Every 2 h.it was filtered through 8 layers of muslin cloth and centrifuged at $5000 \mathrm{~g}$ for $15 \mathrm{~min}$. The supernatant was collected. This procedure was repeated twice and after $6 \mathrm{~h}$. the supernatant was concentrated to make the final volume one fifth of the 
original volume (Parekh, 2005). The extract was then autoclaved at $121^{\circ} \mathrm{C}$ and $15 \mathrm{lbs}$ pressure, and stored at $4^{\circ} \mathrm{C}$.

Solvent Extraction - Ten grams of dried plant material was extracted with $100 \mathrm{ml}$ of solvent kept on a rotary shaker for $24 \mathrm{~h}$. Thereafter, it was filtered and centrifuged at $5000 \mathrm{~g}$ for $15 \mathrm{~min}$. The supernatant was collected and the solvent was evaporated to make the final volume one-fifth of the original volume (Parekh, 2005). It was stored at $4^{\circ} \mathrm{C}$ in airtight bottles for further studies.

Antibacterial assay - The antibacterial activity of different plant species was evaluated by agar well diffusion (Perez et al., 1990) for solvent extracts using Hi-sensitivity test agar (M485) for the assay. The microorganism was activated by inoculating a loop full of the strain in $5 \mathrm{ml}$ of Hi-sensitivity test broth and broth was incubated at $35^{\circ} \mathrm{C}+0.5^{\circ} \mathrm{C}$ for $18-20 \mathrm{hrs}$. After incubation a loopful of actively growing culture was inoculated into $10 \mathrm{ml}$ of Hi-sensitivity broth. Broth was incubated at $35^{\circ} \mathrm{C} \pm 0.5^{\circ} \mathrm{C}$ for $6-8$ hours.0.5 $\mathrm{ml}$ inoculums was inoculated in to the Hi-sensitivity test agar media and after proper homogenization it was poured into $100 \mathrm{~mm}$ petridishes. For the agar well diffusion, a well was made in the seeded plates with the help of a cup-borer $(5 \mathrm{~mm})$. The test compound was introduced in to the well and all the plates were incubated at $35^{\circ} \mathrm{C}+0.5^{\circ} \mathrm{C}$ for $24 \mathrm{hrs}$. Microbial growth was determined by measuring the diameter of the zone of inhibition is presented (Table-1).

\section{Results and discussions:}

Results are given in Table No.1. Successful prediction of botanical compounds from plant material is largely dependent on the type of solvent used in the extraction procedure. Traditional healers use primarily water as the solvent but in our studies we found that plant extracts in organic solvent (Acetone, Chloroform, Methanol and Petroleum ether) provided more consistent antimicrobial activity compared to those extracted in water. These observations can be rationalized in terms of the polarity of the compounds being extracted by each solvent and, in addition to their intrinsic bioactivity, by their ability to dissolve or diffuse in the media used in the assay. 
Ailanthus excelsa, Alstonia scholaris, Grevellia robusta, Moringa oleifera (only water extract is active), Tamarindus indica extracts were totally inactive against all the microorganisms tested. The plants that exhibited antibacterial activity to a certain degree were Acacia Arabica, Callistemom lanceolantus, Casurina equisetifolia, Psidium guajava, Saraca indica and Thuja compacta. Acetone and methanol extract of Acacia Arabica were active against all the bacteria except E.coli. Methanol extract of Callistemom lanceolantus is active against Pseudomonas aeruginosa, Staphylococcus aureus, Bacillus cereus, Bacillus subtilis and Bacillus megaterium.Acetone, methanol and petroleum ether extracts of Psidium guajava are active against all bacteria (Fig.1 and 2) except Bacillus cereus.

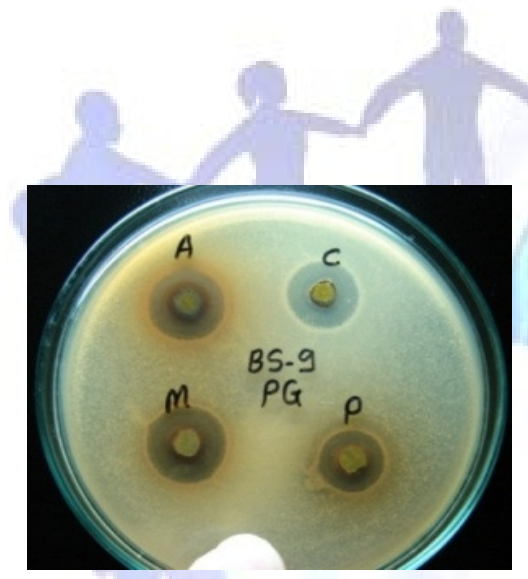

Figure-1.Activity of Psidium guava indica against Bacillus subtilis Acetone extract (A)-16 mm Chloroform extract (C)-15 mm Methanol extract (M)-16 mm Petroleum ether extract (P)-14 mm

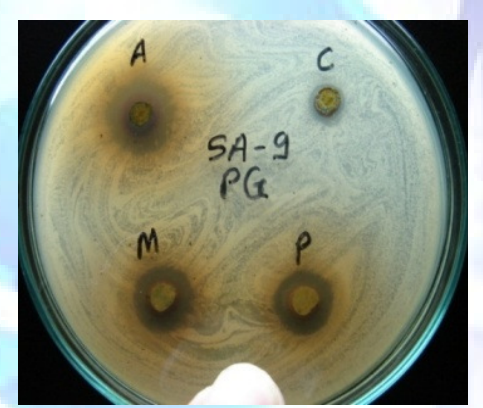

Figure-2.Activity of Psidium guava against Staphylococcus aureus Acetone extract $(A)-15 \mathrm{~mm}$ Chloroform extract (C) Methanol extract (M)-13 mm Petroleum ether extract (P)-13 mm

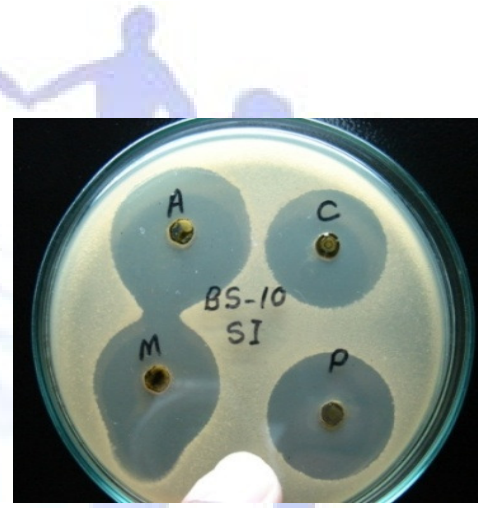

Figure-3. Activity of Saraca against Bacillus subtilis Acetone extract (A)-32 $\mathrm{mm}$ Chloroform extract (C) $-28 \mathrm{~mm}$ Methanol extract (M)-28 mm petroleum ether extract $(\mathrm{P})-28$

$\mathrm{mm}$

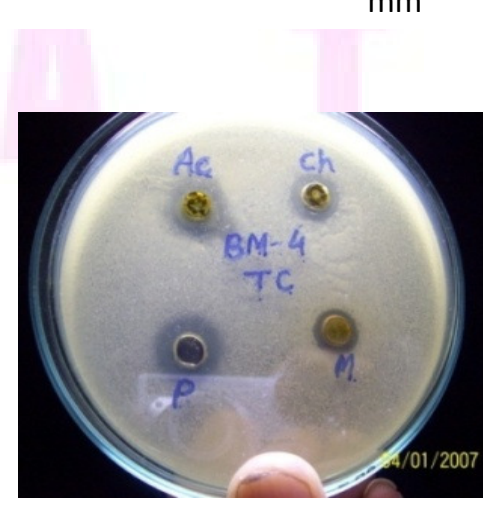

Figure-4.Activity of Saraca indica against Staphylococcus aureus Acetone extract (A)-21 mm Chloroform extract (C)-14 mm Methanol extract (M)-18 mm Petroleum ether extract $(\mathrm{P})-15 \mathrm{~mm}$

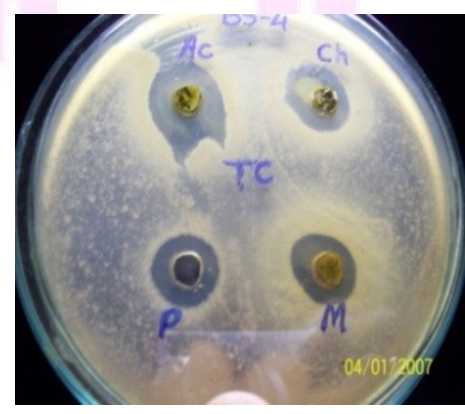

Figure-5.Activity of Thuja compacta against Bacillus subtilis. Acetone extract (A)-17 mm Chloroform extract (C)-13 mm Methanol extract (M)-12 mm Petroleum ether extract $(P)-13 \mathrm{~mm}$
Figure-6. Activity of Thuja compacta against Bacillus megaterium Acetone extract (A)-12 mm Chloroform extract (C)-11 mm Methanol extract (M)-11 mm Petroleum ether extract $(\mathrm{P})-13 \mathrm{~mm}$ 
Acetone, chloroform, methanol and petroleum ether extracts of Saraca indica are active against Staphylococcus aureus (Fig. 4), Bacillus cereus, Bacillus subtilis (Fig. 3), and Bacillus megaterium where as water extract is active against Bacillus subtilis, and Bacillus megaterium. Acetone extracts of Thuja compacta is active against all Gram positive bacteria. Chloroform extract is active against Proteus vulgaris, Bacillus subtilis (Fig. 5), and Bacillus megaterium (Fig. 6). Methanol and petroleum ether extracts are active against Staphylococcus aureus, Bacillus subtilis, and Bacillus megaterium where as water extract is inactive against all the microorganisms. Acetone and chloroform extracts of Vitex negundo are active against Bacillus subtilis, and Bacillus megaterium. Methanol extract is active against Proteus vulgaris, Bacillus subtilis, and Bacillus megaterium. Petroleum ether and water extracts are inactive against all the microorganisms.

Out of 13 plant species, Callistemom lanceolantus, Psidium guajava, Saraca indica and Thuja compacta showed significant activity.the plant extracts were more active against the Gram positive bacteria. This is in agreement with previous reports that plant extracts are more active against Gram positive than against Gram negative bacteria (Vlietinck et al., 1995 ,Rabe et al., 1997).

From present investigation of screening different plant species, the results obtained confirm the therapeutic potency of some plants used in traditional medicine. The results of the present study support the folkloric usage of the studied plants and suggest that some of the plant extracts possesses compounds with antibacterial properties that can be used as antimicrobial agents in new drugs for the therapy of infectious diseases caused by pathogens. The most active extracts can be subjected to isolation of the therapeutic antimicrobials and undergo further pharmacological evaluation. Screening of various natural organic compounds and identifying active agents is the need of the hour, because successful prediction of lead molecule and drug like properties at the onset of drug discovery will pay off later in drug development. 
Table No.1: Antibacterial Study of Cold Extracts of Different Plant Leaves in Different Solvents.

\begin{tabular}{|c|c|c|c|c|c|c|c|c|}
\hline \multirow[b]{2}{*}{ Name of Plants } & \multirow[b]{2}{*}{ Solvent Extracts } & \multicolumn{7}{|c|}{ Microorganisms and zone of inhibition in $\mathrm{mm}$} \\
\hline & & $\begin{array}{l}\tilde{\tilde{0}} \\
0 \\
: 0\end{array}$ & 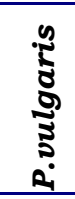 & 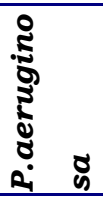 & 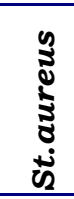 & 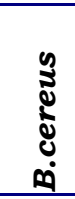 & 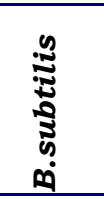 & 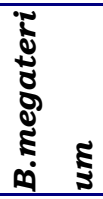 \\
\hline \multirow{5}{*}{ Acacia arabica } & Acetone & $-\mathrm{ve}$ & 12 & $-\mathrm{ve}$ & 20 & 13 & 16 & 13 \\
\hline & Chloroform & -ve & -ve & $-\mathrm{ve}$ & -ve & -ve & 11 & -ve \\
\hline & Methanol & -ve & 13 & 12 & 18 & 13 & 14 & 13 \\
\hline & Petroleum ether & -ve & -ve & -ve & -ve & -ve & -ve & -ve \\
\hline & Water & -ve & -ve & - ve & 12 & -ve & -ve & -ve \\
\hline \multirow{5}{*}{$\begin{array}{l}\text { Callistemom } \\
\text { lanceolantus }\end{array}$} & Acetone & -ve & -ve & 33 & 16 & -ve & 11 & 12 \\
\hline & Chloroform & -ve & -ve & 15 & 10 & -ve & -ve & 11 \\
\hline & Methanol & -ve & -ve & 24 & 16 & 10 & 11 & 12 \\
\hline & Petroleum ether & -ve & -ve & $-v e$ & 12 & -ve & -ve & 10 \\
\hline & Water & $-\mathrm{ve}$ & -ve & $-v e$ & 11 & -ve & -ve & $-\mathrm{ve}$ \\
\hline \multirow{5}{*}{$\begin{array}{l}\text { Casurina } \\
\text { equisetifolia }\end{array}$} & Acetone & -ve & -ve & -ve & 13 & -ve & 14 & 11 \\
\hline & Chloroform & -ve & -ve & -ve & -ve & -ve & 14 & -ve \\
\hline & Methanol & -ve & -ve & -ve & 12 & -ve & 11 & -ve \\
\hline & Petroleum ether & -ve & -ve & -ve & -ve & -ve & -ve & -ve \\
\hline & Water & -ve & -ve & -ve & -ve & -ve & -ve & -ve \\
\hline \multirow{5}{*}{$\begin{array}{l}\text { Psidium } \\
\text { guajava }\end{array}$} & Acetone & 17 & 15 & 21 & 15 & -ve & 16 & 11 \\
\hline & Chloroform & $-v e$ & -ve & $-\mathrm{ve}$ & -ve & -ve & 15 & -ve \\
\hline & Methanol & 17 & 15 & 18 & 13 & -ve & 16 & 10 \\
\hline & Petroleum ether & 16 & 16 & 18 & 13 & -ve & 14 & 10 \\
\hline & Water & -ve & 11 & -ve & 12 & -ve & -ve & -ve \\
\hline \multirow{5}{*}{ Saraca indica } & Acetone & -ve & -ve & -ve & 21 & 24 & 32 & 24 \\
\hline & Chloroform & -ve & -ve & -ve & 14 & 18 & 28 & 18 \\
\hline & Methanol & $-v e$ & $-v e$ & $-\mathrm{ve}$ & 18 & 15 & 28 & 21 \\
\hline & Petroleum ether & -ve & -ve & -ve & 15 & 17 & 28 & 20 \\
\hline & Water & - ve & -ve & -ve & -ve & -ve & 17 & 10 \\
\hline \multirow{5}{*}{ Thuja compacta } & Acetone & -ve & -ve & -ve & 16 & 14 & 17 & 12 \\
\hline & Chloroform & $-v e$ & -ve & 13 & -ve & -ve & 13 & 11 \\
\hline & Methanol & - ve & $-v e$ & - ve & 12 & -ve & 12 & 11 \\
\hline & Petroleum ether & $-v e$ & -ve & $-v e$ & 12 & -ve & 13 & 13 \\
\hline & Water & -ve & -ve & $-\mathrm{ve}$ & -ve & -ve & -ve & -ve \\
\hline \multirow{4}{*}{ Control } & Acetone & -ve & 10 & -ve & -ve & -ve & -ve & -ve \\
\hline & Chloroform & -ve & -ve & 14 & -ve & 12 & 10 & 10 \\
\hline & Methanol & -ve & -ve & -ve & 12 & -ve & 10 & -ve \\
\hline & Petroleum ether & -ve & -ve & -ve & -ve & -ve & -ve & -ve \\
\hline
\end{tabular}

\section{References:}

Ahmad I., Mehmood Z. \& Mohammad F. 1998. Screening of Some Indian medicinal plants for their antimicrobial properties.1998.J Ethnopharmacol 62:183-193.

Bhavani S.M. \& Ballow C.H., 2000. New agents for Gram positive bacteria. Curr Opin Microbiol 3:528-534.

Chakravarthy B.K. \& Gode K. D., 1985. Isolation of epicatechin from Pterocarpus marsupium and its pharmacological action. Planta Medica 1:5659.

Chung P. Y., Chung L. Y., \& Ngeow Y. F., 2004. Antimicrobial activities of Malaysian plant species. Pharm Biol 42:292-300. 
Clark A. M., 1996. Natural products as resource for new drugs. Pharm Res 13:1133-1141.

Cordell G. A., 2000. Biodiversity and drug discovery a symbiotic relationship. Phytochemistry 55:463-480.

Davis J., 1994. Inactivation of the antibiotics and the dissemination of resistance genes, 1994. Science 264 : 375-385.

De Boer H. J., Kool A. \& Broberg A., 2005. Antifungal and antibacterial activity of some herbal remedies from Tanzania.J Ethnopharmacol 96:461469.

Ebi G. C. and Ofoefule S. I., 2000. Antimicrobial activity of Pterocarpus osun stems. Fitoterapia 71:433-435.

Nair R, \& Chanda S. V., 2004. Antimicrobial Activity of Some medicinal plants of Saurashtra region. J Tissue Res 4:117-120.

Nair R., Kalariya T. \& Chanda S., 2005. Antimicrobial Activity of Some selected Indian medicinal flora.Turk J Biol 29:41-47.

Parekh J., Nair R. \& Chanda S., 2005. Preliminary screening of some folkloric plants from western India for potential antimicrobial activity. Indian J. Pharmacol.

Perez C. Paul M. \& Bazerque P., 1990. Antibiotic assay by agar-well diffusion method. Acta Biol Med Exp 15:113-115.

Prusti A., Mishra S. R., Sahoo S. and Mishra S. K., 2008. Antimicrobial Activity of Some Indian Plants. Ethnobotanical Leaflets 12:227-230.

Rabe T. \& Van Staden J., 1997. Antibacterial activity of South African plants used for medicinal purposes. J Ethnopharmacol 56:81-87.

Vlietinck A., J. van, Hoof L. \& Totte J., 1995. Screening of hundred Rwandese medicinal plants for antimicrobial and antiviral properties. J. Ethnopharmacol 46:31-47. 